\title{
Şırnak Geleneksel Eı Sanatlarının Turistik Ürün Olarak Değerlendirilmesi
}

\section{Evaluation of Şırnak Traditional Handicrafts as Touristic Products}

\author{
Sedat Çelik, ${ }^{\mathrm{a},{ }^{*}}$ Lutfullah Sadi Toprak ${ }^{\mathrm{b}}$ \\ ${ }^{a}$ Dr. Öğr. Üyesi, Şırnak Üniversitesi, Turizm ve Otel İşletmeciliği Yüksekokulu, Konaklama İşletmeciliği Bölümü, 73000, Şırnak/Türkiye. \\ ORCID: 0000-0002-4541-6355
}

b Öğr. Gör., Van Yüzüncü Yıl Üniversitesi, Gevaş Meslek Yüksekokulu, Turizm ve Otel İşletmeciliği Bölümü, 65700, Van/Türkiye. ORCID: 0000-0002-3079-920X

\section{MAKALE BILGİSI}

\section{Makale Geçmişi:}

Başvuru tarihi: 02 Mart 2018

Düzeltme tarihi: 30 Mart 2018

Kabul tarihi: 04 Nisan 2018

\section{Anahtar Kelimeler:}

Geleneksel El Sanatları

Somut Kültürel Varlıklar

Şırnak

Türkiye

\section{ARTICLE INFO}

\section{Article history:}

Received 02 March 2018

Received in revised form 30 March 2018

Accepted 04 April 2018

\section{Keywords:}

Traditional Handicraft

Tangible Cultural Assets

Şırnak

Turkey

\section{ÖZ}

Geleneksel el sanatlarının yok olmasının önüne geçebilmenin bir yolu da üretilen ürünlerin turizm sektöründe hediyelik eşya olarak değerlendirilmesidir. Bu çalışmada öncelikle el sanatlarının turistik ürünler olarak kullanılması çerçevesinde Şırnak iline özgü el sanatlarının (baston, kilim, Şal-Şepik vb.) bilinilirliğinin arttırılması ve turistik ürün olarak kullanılabilmesi üzerinde durulmuştur. Araştırmada nitel araștırma yöntemi kullanılarak öncelikle literatür taranmış daha sonra görsel unsurlarla Şırnak ilinin var olan geleneksel el sanatları potansiyeli ortaya konmuştur. Araştırmada elde edilen sonuçlara göre, kültür turizminin bir öğesi olan geleneksel el sanatlarının bulunduğu bölgeye başta sosyal, kültürel olmak üzere farklı boyutlarda katkı sağlamasının en önemli araçlarından biri turistik ürün olarak kullanılabilmesidir. Şırnak ilinde var olan el sanatları potansiyelinin yok olmasını önlemek ve turistik bir ürün olarak tanıtılması ve pazarlanması gerekmektedir.

\section{A B S T R A C T}

One way of avoiding the disappearance of traditional handicrafts is to consider the produced products as souvenirs in the tourism sector. In this study, increasing the awareness of handicrafts unique to Şırnak province and using handicrafts as touristic products in the frame of using handicrafts as touristic products have been emphasized. Qualitative research method was used in the research. Firstly, the literature was searched and then the traditional handicrafts of Sirnak Province were presented with visual elements. Traditional handicrafts is an element of cultural tourism and its being used as a touristic product is one of the most important tool to provide contributions to the regions where it exists in different dimensions such as cultural and social dimensions. The handicrafts existing in Şırnak Province are required to be advertised and marketed as a touristic product in order to prevent the disappearance of the potential.

\section{Giriş}

Toplumların sahip olduğu somut ve soyut kültürel değerlerin sürdürülebilirliği ve geliştirilebilmesi kuşaklar arasındaki etkileşimin devam ettirilmesi açısından oldukça önemlidir. El sanatları da toplumların kültür taşıyıcılarından birisidir. Bu bağlamda kültür turizminin önemli unsurlarından olan el sanatları bir toplumun, üretim tüketim alışkanlıklarını, beğenilerini, giyim kuşamını, yaşam tarzını yansıtan değerlerdendir. Ancak teknolojinin gelişmesi ile birlikte el sanatları olarak ortaya konulan değerlerin gittikçe seri üretim makinelerinden insanlara ulaşır hale geldiği görülmüş ve dolayısı ile el sanatlarının icra edilmesi ve sürdürülmesi zor bir hal almıştır. Fakat turizm sektörünün gelişmesi ile hediyelik eşya ve el sanatlarına olan talebin arttı̆̆ gözlemlenmiştir. Bundan dolayı özellikle kültür turizminin yapıldı ğı destinasyonlarda el sanatlarının kısmen de olsa icra edildiği görülebilmektedir. Bir yöreyi, kenti ya da ülkeyi; coğrafyasından başlayarak tarihi, arkeolojisi, kültürü ve kültürü oluşturan el sanatları gibi değerleri kısacası dününü ve bugününü kapsayan turlar kültür turizmi için önemli bir çekim kaynağıdır (Köybaşı, 2006: 24). Turizm

* Sorumlu yazar/Corresponding author.

e-posta: s.celik@sirnak.edu.tr 
faaliyetlerinin gelişmesine sosyal, kültürel, ekonomik alanda önemli katkılar sağlayan el sanatları turistler için satın alınan özgün ürünlerle eşsiz deneyimler sunmaktadır. Ayrıca üretildiği bölgenin tanıtımına katkı sağlayarak turistik çekicilik oluşturmasıyla yöre halkına yeni iş imkânları sağlamaktadır (Bayazit vd., 2012: 902).

Özellikle sanayi devrimiyle birlikte ortaya çıkan makineleşme ve buna bağlı olarak az enerji ve insan gücüyle hızlı üretimin sağlanması el sanatlarını olumsuz etkileyen değişimler olmuştur. Bu değişim toplumsal düzeyde sosyal, kültürel ekonomik her alanı etkilemiş ve bu durumun olumlu ve olumsuz sonuçları ortaya çıkmıştır (Kılıçarslan vd., 2017: 35). El sanatları ile turizm faaliyetleri arasındaki yakın ilişki turistlerin otantik ürünler ve hediyelik eşya satın alma davranışlarıyla somutlaşmaktadır. El sanatları gibi geleneksel olan ürünlere olan ilginin artması turistlerin sadece kültürel değerlere vermiş oldukları önemi ortaya çıkarmakla kalmaz; aynı zamanda ekonomik anlamda üretildikleri bölgenin kalkınması ve yeni istihdam olanaklarının artması olumlu sonuçlar olarak değerlendirilmektedir (Bayazit vd., 2012: 902).

Geleneksel ürünlerin ticari amaçlarla kullanılması ve bunların kullanım alanlarının genişlemesi gibi konularda turizm önemli bir rol üstlenmiştir. Bu durum geleneğin doğal ortamının dışında kullanılmasından dolayı folklorizm kavramını ortaya çıkarmaktadır (Şahin, 2009). Folklorizm tanımlamalarına bakıldığında genel olarak "folklor ürünlerini bağlamından kopararak başka ve daha geniş alanlarda kullanma" (Bendix, 1997: 337) olarak ifade edildiği görülmektedir. El sanatlarının, halay ve dans gösterilerinin yöresel kıyafetli figürlerle (bebek vb.) turistik ürün olarak kullanılması bu duruma örnek gösterilebilir. Dolayısıyla el sanatlarının ticari amaçlarla kullanılması fabrikasyon ürünlerle ve destinasyonun kültüründe olmayan sonradan ortaya konulan ürünlerin ortaya çıkmasına neden olmaktadır. $\mathrm{Bu}$ durum kültürün yozlaşmasına ve değişmesine neden olabilmektedir. Bunun önüne geçmek için denetleme mekanizması geliştirilmelidir.

Ülkemizde kültürün dezenformasyona, yozlaşmaya uğramasını engellemek, somut ve soyut kültürel değerleri gelecek kuşaklara aktarmak, bunların ulusal ve uluslararası alanda bilinilirliğini arttırmak için önemli adımlar atılmıştır. UNESCO tarafindan 2003 yilında kabul edilen Somut Olmayan Kültürel Mirasın Korunması Sözleşmesi’ne Türkiye 2006 yılında taraf olmuştur. Kültür ve Turizm Bakanlığı Araştırma ve Eğitim Genel Müdürlüğü ilgili sözleşmenin uygulanabilmesi için icracı birim olmuştur. Her ne kadar kültürel çalışmalar bakanlıkların görevleri olsa da üniversitelerin de kültürlerin korunması ve tanıtılmasında önemli rolleri bulunmaktadır.

Ülkemizin bilinen birçok somut ve soyut kültürel varlıkları olmasının yanında henüz pek bilinmeyen kültürel varlıklar da mevcuttur. Tam bu noktada, bu çalışma ülkemizin kadim şehirlerinden Şırnak ilinin sahip olduğu geleneksel el sanatlarının ulusal ve uluslararası alanda bilinilirliğini arttırmayı amaçlamıştır. Ayrıca baston, kilim, şal-şepik vb. bu değerlerin turistik ürün olarak kullanılabilirliğine yönelik toplumu bilinçlendirme gayretini taşımaktadır. Bu amaçlar kapsamında öncelikle konuya ilişkin literatür incelendikten sonra mevcut el sanatlarının durumu irdelenerek var olan potansiyel ortaya konmuştur. Daha sonra somut kültürel varlıklardan olan el sanatlarının korunması ve geleceğe taşınması için önerilerde bulunulmuştur. Şırnak ilinde benzer bir çalışmanın yapılmamış olması araştırmanın burada yapılmasında etkili olmuştur.

\section{Alanyazın Taraması}

El sanatları başlangıçta insanların ve toplumların barınma, korunma gibi ihtiyaçları doğrultusunda ortaya çıkan yüzyıllar boyunca toplumların değerlerini, yaşam tarzlarını birikimlerini işleme veya süsleme biçiminde yansıtan daha çok el emeği ile üretilen kültürel değerlerdir (Sarıkaya Hünerel ve Er, 2012: 181). Bu açıklamadan hareketle geleneksel el sanatları; bir ulusun veya bir toplumun geçmişten günümüze oluşmuş ve olgunlaşmış kültürünün donatılmış bir yansımasıdır denilebilir. Diğer bir tanımlamaya göre "el sanatları bir bölgenin zamanın kültürel niteliklerini tasvir eder ve basit aletlerle doğrudan zanaatkârlar tarafından el ve ayaklarla çalıştırılan sanatsal özellikler taşıyan ve genelde küçük bir endüstriye dayanan ve kitlesel üretim esaslı olmayan ürünlerdir" (Zargham, 2007). Dolayısı ile el sanatı belli tarihi ve kültürel kaynağı ve birikimi olan, bu birikimin geçmişten günümüze aktarılmasıyla gelen sanatsal ve kültürel değeri olan el yordamıyla ya da atölye veya fabrika gerektiren ticari ya da bireysel amaçlı turistik ve hatıra eşyası üretimine dayalı uğraşıların ortak adı olarak tanımlanabilir (Ölmez ve Etikan, 2008: 381). Kisacası bir ülkenin veya toplumun anane ve değerlerinin geçmişten günümüze korunarak yaşatılmasında önemli işlevi olan el sanatları taşıdığı değer yargıları ile geçmişten geleceğe köprü görevi gören bir kültür taşıyıcısıdır (Kılıçarslan vd., 2017: 35). Estetik anlayışının aynası, el emeği ve göz nuru özgün yapıtlardır. Bu yapıtlar, günlük kullanım gereçlerinden süsleme araçlarına ve armağan nesnelerine varıncaya kadar geniş bir yelpazede karşımıza çıkmaktadır (İdiman, 1999; Zargham, 2007).

Özellikle, kapitalist yaşam tarzının, insani deneyimleri, fikirleri, pratikleri ticarileştirmesi, artan kitle iletişim olanaklarıyla bu ticarileșen "ortak hayat biçimlerinin" sadece milli sınırlar içinde değil, dünya ölçeğinde de paylaşılması, kültür tanımlamasına yeni parametreler getirmekte (Okutan, 2012: 13) ve bu durum kültürel unsurlar arasında yer alan el sanatlarının önemini artırmaktadır. $\mathrm{Bu}$ bağlamda kültür-turizm ilişkisi incelendiğinde tarihsel, kültürel değerlerin, yapıların ziyaret edilmesi ile ortaya çıkan turizm faaliyetleri kültür turizmi kapsamında değerlendirilmektedir (Tunç ve Saç, 1998: 32). Geçmiş toplulukların kültürlerinin gelecek kuşaklara aktarılmasında tarih boyunca yazılı kaynaklar kadar etkili olan el sanatları ürünleri her zaman iyi bir iletişim aracı olmuş ve bizlere çağlar öncesinden ışık tutmuştur. El sanatları; eğitim, sosyal ve ekonomik gelişmeye ve ruh sağlığına olumlu katkıları ile ayrıca toplumun paylaşma ve yardımlaşma duygularının da gelişmesinde önemli rol oynamaktadır (Akpınarlı ve Onuk, 2005: 27).

Turistik ürün, ikamet edilen yerde karşılanamayan gereksinimleri giderme niteliği olan mevcut ve potansiyel mal ve hizmetlerdir (Rıaoğlu, 2016: 192). Usta (2014: 114) ise turistik ürünü tüketim isteği uyandıran doğal, kültürel ve sosyal verilerin bu isteği arttıracak hizmet ve faaliyetlerle birlikte değerlendirilmesi sonucunda oluşan karma bir ürün olarak açıklamaktadır. Turizmde ürün iki şekilde değerlendirilmektedir. Bunlardan birincisi, bir destinasyonun sahip olduğu tüm doğal, tarihi ve turistik 
kaynakların varlığıyla ortaya çıkan turizm ürünüdür. İkincisi ise, turistlerin ikamet ettikleri yerden hareket etmeleri ile başlayan ve tatil yapmalarına olanak tanıyan tüm hizmetler yani bir paket turu oluşturan turistik hizmetlerin türüdür (Hacıŏlu, 2008: 39). Bu açıklamalardan hareketle turistik ürün, turistlerin seyahatleri esnasında ihtiyaçlarına cevap veren mal ve hizmetler ile onları seyahate yönelten tarihi, kültürel doğal kaynakların tümü olarak değerlendirilebilir.

Turistlerin farklı kültürlerle karşılaşma arzusu ve maddi olan ve olmayan unsurlar, dünya genelinde gerçekleşen kültürel miras turizminin muazzam büyümesindeki güçlü motivasyon kaynağıdır. Bunlar yerli ve yabancı turistlerin ilgi duyduğu unsurlardır. Turizmde farklı kültür alanlarını ziyaret etmek ana çekici nokta olarak kabul edilir. Soyut kültürel unsurlara verilen önem ise ikinci sırada yer almaktadır. Birçok turist geleneksel el sanatlarının yapıldığı mağaza ve atölyelerde mola vermektedir. Kaliteli bir el sanatı alınırken turistlerin anılarını hatırlatmasının yanı sıra, onu gören kişilerinde ilgisini uyandırır. El yapımı nesneler somut unsur, bunu yapan zanaatkârlar ise soyut kültür unsuru olarak turizm kaynakları arasında değerlendirilmektedir. Bu kaynakların turizm amacı ile kullanılması sürdürülebilir kalkınma için büyük önem taşımaktadır. Sanatsal objelerin imalatı ve istihdam olanakları oluşturması ile bu önem görülebilmektedir. Ek olarak, bu tür nesneler, bir topluluğun değerlerini ve maneviyatını sunduğu araçlardan biridir ve daha önemlisi ise kuşaklar boyunca iletilen sosyal-kültürel kimliğin hayati bir parçasını oluşturmaktadırlar. El sanatlarının bu yararları, turizme bağımlılığı olan ülkeler için oldukça önemlidir. Örneğin Ürdün'ün GSYİH'nin \%14'ünü turizmden elde edilen gelir oluşturmaktadır. İngiltere'nin en büyük ihracat sektörü, ikinci en büyük özel sektör işvereni, en yüksek döviz üreticisi turizm sektörüdür (Mustafa, 2011). Ek olarak Türkiye'nin dış ticaret açığının kapanmasında turizmin payı 2017 yılında \%34,25, ihracat gelirleri içindeki pay1 2016 y1lında $\% 15,5$, turizmden elde edilen gelir ise 2017 yılında 26 milyar doların üzerindedir (TÜRSAB, 2017). Dolayısı ile ülkemiz içinde turizm oldukça önemli bir sektördür.

Türkiye'de turistik alışverişlerde daha çok halıcılık, kuyumculuk, seramikçilik, taş süslemeciliği, ağaç oymacılığı, ebru, hat, minyatür ve tezhip sanatları dekoratif amaçlı tercih edilen el sanatları arasındadır (Öter, 2010). Turistlerin özel ürün arayışı ile el sanatlarının gelişimi sağlanmaktadır. Bu noktada sanayileşme ile birlikte gelen taklit ve seri ürün imalatı ile zanaatkârların gittikçe azalmasını (Durand ve Freemond, 1979'den aktaran: Öter, 2010) engelleyen yegâne sektör olarak turizm gösterilebilir.

Turizm sektöründeki özel ilgi turizminin artan rolü ile birlikte destinasyonlardaki gelişme çeşitli nesne ve hizmetlerde talep meydana getirenlerden biri de el sanatlarıdır. Turizmin gelişmesi ile birlikte el sanatları ve hediyelik eşya sektörünün de geliştiği görülmektedir (John, 2014). Kültürel hediyelik eşya satışı, birçok ülkede, turistik mekânlar ve ulusal turizm kimliğinin tanıtılması, ziyaretçilerin sayısının artırılması ve tekrar ziyaretlerin teşvik edilmesinde önemli bir faktör olarak kabul edilmektedir (Tjoa ve Wagner, 1998). Ek olarak, el işçiliği ülkelerin kültürel turizm merkezi haline gelmelerinde sürdürülebilir ekonomik büyümeye ve istihdama katkıda bulunan turizm sektörünün geliştirilmesinde katalizör görevi görmektedir (Zarghami, 2007).
Turistin hediye götürmek, dekoratif ürün olarak veya değerli bir ürün olarak satın aldığı el sanatlarının sadece kültürü koruma ve ekonomik katkısı değil aynı zamanında ülkenin tanıtılmasında önemli rol oynamaktadır (Bayazit vd., 2012).

Bayazit vd. (2012) yılında yapmış oldukları çalışmalarında bölgedeki el sanatları ustalarının çalışacak eleman ve zamanı geldiğinde işlerini devredecek kalfa veya ikinci nesil akraba bulmakta zorlandıkları bu sebepten geleneksel el sanatları konusunda bölge halkına yönelik mesleki eğitimler verilmesi gerektiği sonucuna ulaşmışlardır. Can (2013) yılındaki çalışmasında ülkemizde nitelikli el sanatları ürünlerinin günümüzde hala yapıldığının fakat bu meslek ile ilgili uğraşanların en önemli sorunlarının örgütlenme olduğu sonucuna ulaşmıştır. Öter (2010) yılında yapmış olduğu çalışmasının sonucunda Türkiye'de el sanatlarının korunması ve pazarlanması için yeterince çaba gösterilmediği bu sebepten Türkiye'de üretimi devam eden el sanatları türlerinin tespit edilip bunun resmi tasnif şeklinde gerçekleştirilmesi gerektiğini, ayrıca ülkemizdeki el sanatçılarının sayımla kayıt altına alınması gerektiğini vurgulamıştır. Kılıçarslan vd. (2017) yılındaki çalışmalarının sonucunda el sanatçıları ustalarının ürünlerini ortaya koymalarındaki ana amaçlardan birinin ekonomik gelir olduğunu ve bu sebepten geleneksel kullanım amacının dışında fazla gelir getirmesi için dekoratif eşya ve aksesuar olarak üretilmeye başlandığını vurgulamışlardır. Akköprü (2015) yılındaki çalışmasında günümüzde geçmişe göre önemini yitirmek üzere olan el sanatlarına verilen desteklerin küçümsenemeyeceği, el sanatlarının yaşatılması için verilen eğitimler ile bu sanatı gelecek nesillere aktaracak çok sayıda yeni ustanın yetiştiği, bu alanda verilen destek sonucu el sanatları ürünleri üretilerek ekonomik bir girdi ve istihdam alanı sağlandığı ve Van ekonomisine yüksek miktarda girdinin oluştuğu sonucuna ulaşmıştır. Sarıkaya Hünerel ve Er (2012) yılındaki çalışmasında el sanatlarının halk kültürü açısından önemine değinmişlerdir. Etikan ve Çukur (2011) yılındaki çalışmasında kırsal turizm faaliyetlerinin etkisi ile başlayan değişimin el sanatlarında da değişime neden olduğu, bu değişimin el sanatlarındaki ekonomik gelir ön planda tutularak turistlerin tercih ettikleri cüzdan, pano, kemer gibi ürünlere yöneldiği ve bunun sonucunda geleneksel şeklinden farklı boyutlarda üretilmeye başlandığı sonucuna ulaşmışlardır. Özcüre ve Yavuz (2006) yılındaki çalışmalarında kaybolmaya yüz tutan el sanatlarının, yeniden canlandırılması ve değerlendirilmesi amacıyla, el sanatları ürünlerinin ve bunların yaşatıldığı köy ve yerleşim yerlerinin tanıtılmasının, bu işlerle geçimini temin edenlere finansal kaynak sağlanmasının, usta- çırak geleneğinin canlandırılmasının, turizm merkezleri ile iletișim kurularak, üretilen eserlerin satışlarının sağlanmasının, el sanatlarının tanıtımı ve satışı için sergi ve fuarlar düzenlenmesinin önemi vurgulanmıştır. Yanar ve Arlı (2014), ise çalışmalarında turistik hediyelik eşyalarda kimlik bilgisinin bulunmasının önemine değinmiştir.

Literatür incelendiğinde ulusal ekonomik kalkınmada el sanatlarındaki gelişimin etkisi olduğu görülmektedir (Zargham, 2007). Ancak el sanatlarının daha iyi kullanılabilmesi için turizm sektörünün geliştirilmesi gerekir (Nyawo ve Muganbizi, 2015). El sanatları gelişmekte olan ülkelerin ekonomilerinde önemli bir rol oynamaya devam etmektedir; kendi başlarına büyük imalat faaliyetleri oluşturmazlar, ancak genelde ek istihdam yaratma ve hem kırsal hem de kentsel nüfus için yaşam seviyesini 
yükseltmenin tek yolu olarak kullanılabilirler (Zargham, 2007).

\section{3. Şırnak'ta Eı Sanatları}

Yukarıda üzerinde durulan geleneksel el sanatlarının Şırnak ilindeki durumuna bakıldığında geleneksel el sanatları ile yapılan baston, kilim, şal-şepik ve fistan gibi kültürel değerlerin olduğu tespit edilmiştir.

\section{1. Şırnak Bastonu}

Tüm kültürlerde kullanılan ve genellikle yaşlıların yürürken destek aldıkları bir araçtır. Şırnak kültüründe aynı amaçlarla kullanmanın yanında, kırsalda vahşi hayvanlardan korunmak amacıyla da kullanılan bir üründür. Yörede Guhşegi oyununda sopa olarak ta kullanılan bu baston ayrica kullanan kişiye itibar kazandırmaktadır. Baston kullanımı yüzyıllar boyunca süregelen bir gelenektir. Baston birine hediye edildiğinde karşıdaki kişiye çok değerli bir hediye verilmiş olarak algılanmaktadır. Şırnak'ta var olan baston kültürünün mimarları, baston ustaları gittikçe azalmakta ancak bu mesleği icra eden kişilerin günümüzde halen varlığı da sevindiricidir bir durumdur. Şırnak bastonu üç çeşit olarak üretilmektedir. Bunlar; Gopal (desenli, demir, ağzı geniş), Sikke ve Adude şeklindedir. Bu bastonların yapımında daha çok Badem Ağacı, Meşe Ağacı, Çilu, Dare Deyindar, Yabani Kiraz Ağacı (Belaluk), Mahlep Ağacı (Kenêr), Tavi Ağacı, Bıttım (Ben) Ağac1, Meral Ağac1, Peqpequ Ağac1, Ayva Ağacı (Bih), Dut Ağacı (Darê Tu), Yabani Palamut (Berû), Erguvan (Zizelax), Riman, Alıç(Guhiş) Ağacı, Dar Gez, Dar Şirinok kullanılmaktadır (Baz vd., 2013).

\section{Resim 1. Şırnak Bastonu}

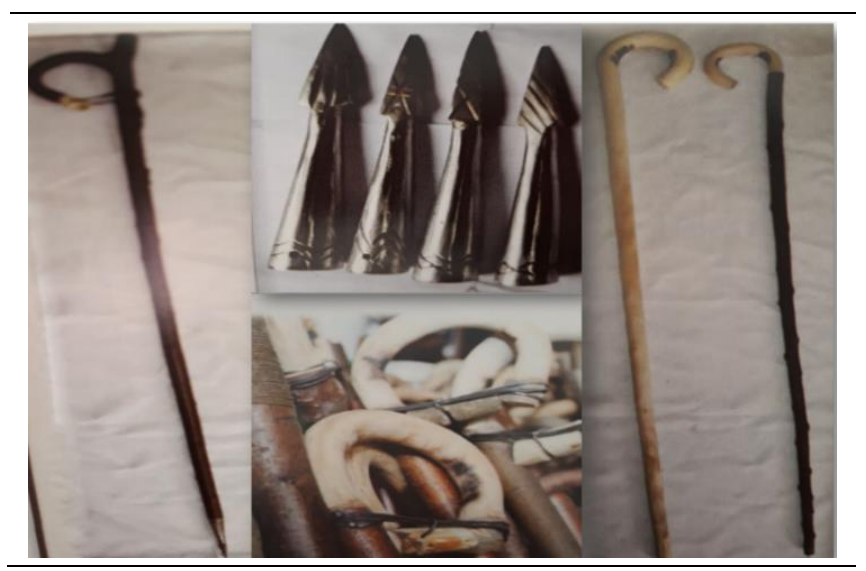

Kaynak: Baz vd. (2013)

Özellikle sonbaharda baston için toplanan veya satın alınan ağaçlar (meşe, mahlep, çilu vb. ağaçlar) ile bastonun bükülecek kısmı ateşte 1sıtılır ve bükme aracında bükülür. Bükülen kısım ip veya telle bastonun sırtına bağlanır. Bundan sonra baston kurumaya birakılır ve bu zaman dilimi yazın 4-5 gün kışın 1 aya kadar sürer. Daha sonra teller açılır, çatlama vs. varsa talaş ve yapıştırıcı ile doldurulur. Ağacına göre soyma işlemi gerçekleştirilir. Zımpara işlemi yapılır. Daha sonra parlatmak için sıvı yağ veya cila sürülür. Sikke bastonunda bunlardan farklı olarak bastonun ucu sivriltilerek ucuna demir uç (Ser Sikke) takılır. Şırnak Bastonu genelde süslemesizdir. En kıymetli olanı sikke bastonudur (Baz vd., 2013).

\subsection{Kilim}

Şırnak yöresine ait has desenleri ve dokunuş biçimi ile kendisini kabul ettirmiş bir el sanatıdır. Jirki ve Guyan kilimleri en çok bilinen kilimlerdir. Bu kilimleri daha çok Jirki ve Guyan aşiretlerinin yoğun olduğu yerlerde yapıldıklarından bu adla adlandırılmaktadır. Kilimlerde gerçek yün ve doğal kök boya kullanılmaktadır. Bu kilimler kadınlar tarafindan kendi evlerinde tezgâhlarda dokumaktadırlar. Desenler genellikle yöre halkının dini inancını, yaşantısını, başından geçmiş acı tatlı olayları, doğa ile iç içe yaşantısını, doğanın şekil ve özelliklerini ifade etmektedir. Halen günümüzde elli'ye yakın motif kilimlerde kullanılmaktadır (Bayazit vd., 2012). Bazı desen isimleri ve yörede ifade ediliş şekli şöyledir; Yayla Gülü (Gılagever), Küpeli Gül (Gılagaharik), Sâriye Gül (G1lsariye), Kurbağa (Bekık), Guyan Aşireti Benzetmesi (Guyani), Sevgili (Yarıyu), Yıldız (Steyre), Bey Evleri (Mala Mirik) (Top, 2009). Kilim sanatının icra edilmesi için çeşitli kurumlar tarafından köy ve ilçelerde kilim dokuma kursları açılmıştır. Bu kültürün sürdürülebilmesi açısından oldukça önemlidir.

Resim 2. Şırnak Kilimi

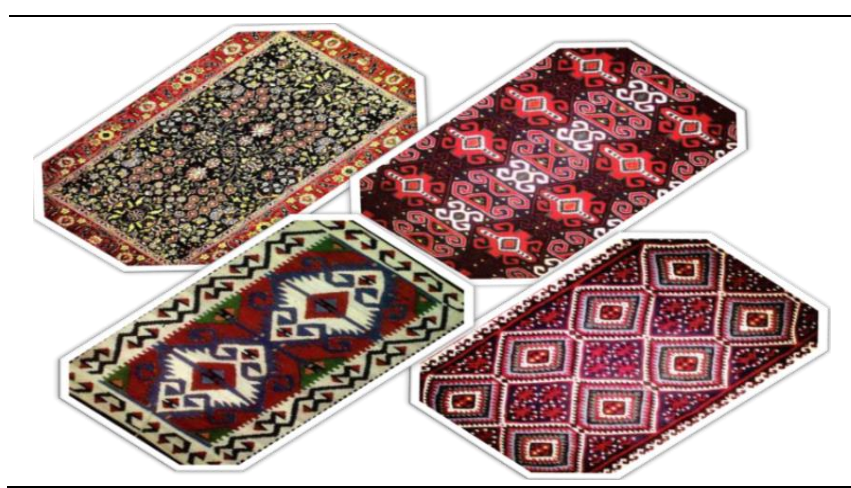

Kaynak: İde Sanat (2005)

\subsection{Kıyafetler (Şal, Şapik, Yelek ve Fistan)}

Şırnak ili erkek kıyafetleri geçmişten son zamanlara kadar yörede tiftik keçisinden elde edilen 'Gej' adı verilen yünden yapılmaktadır. Halen de birkaç işletme tarafından ve bazı meslek kurslarında üretimi yapılmaktadır. Elbiselerin boyası doğal kök boyalardan yapılır. Gej büyük kazanlar içerisinde yıkanıp kurulandıktan sonra ayıklama işlemi yapılır. Doğal kök boyalar büyük kazanlarda hazırlandıktan sonra Gej içine atılır ve belirli bir süre beklenir. Boya kazanından çıkarılan Gej kurumaya birakılır. Gej kuruduktan sonra 50-55 derece sıcaklıktaki suda yıkanır ve kurutulur. $\mathrm{Bu}$ işlemden sonra Teji adı verilen ucu topuklu, çengelli bir çubukla sarmalanarak iplik haline getirilir. Son olarak hazırlanan bu ipler fitillendikten sonra Şal-Şapik yapmak için hazır hale gelmiş olur (Top, 2009). Eskiden sadece erkek giysileri için kullanılan bu kumaş son zamanlarda kadınlar için ve ceket, kıravat yapımı içinde kullanılmaktadır. Şal geniş boru paçalı pantolon, Şapik (göynek) uzun kollu giysi, Yelek; şapiğin üstüne giyilir (Top, 2009). Şırnak yöresel kadın giyimleri genellikle fistan (entari) dır. Fistan kadife veya çemçem kumaşlarından yapılan, ayaklara kadar uzanan tek parça elbisedir. Altta kıras denilen kumaş giyilir. Üstlerine renkli yelekler giyerler. Levendiler kol bileklerine sarılır. Bele ince kumaş ve başlarına kıtan (tülbent) bağlanır. Şırnak’ta neredeyse her aşiretin ve ilçenin farklı tasarımlarda kadın 
giysileri bulunmaktadır (Şırnak Kültür ve Turizm Müdürlüğü, 2017).

Resim 3. Yöresel Kadın (Fistan/Kıras)-Erkek (Şal-Şepik) Kiyafetleri

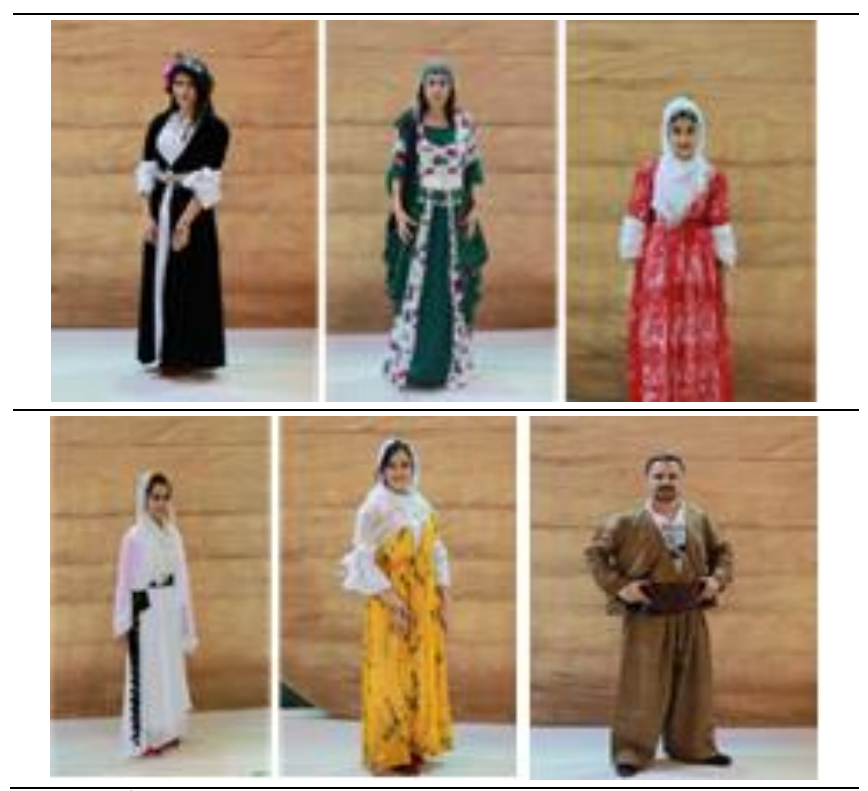

Kaynak: İbrahimoğlu (2018) Foto Arşivi

Yukarıda en çok kullanılan ve önemli görülen geleneksel el sanatları ürünleri açıklanmıştır. Bunlar dışında oya işleme, heybe ve çorap yapımı gibi geleneksel el sanatları ürünleri Şırnak'ta yapılmaktadır.

\section{Sonuç ve Öneriler}

$\mathrm{Bu}$ çalışmada, geleneksel el sanatları ve turizm ilişkisine değinilmiştir. Şırnak'ın geleneksel el sanatları ürünlerinin turistik ürün olarak kullanılabilirliği üzerinde durulmuştur. Geleneksel el sanatları toplumların tarihini, kültürünü ve değerlerini ortaya koyan meşakkatli bir zanaattır. Toplumun hafızasını nakışlara işleyen zanaatkârlar aynı zamanda değerlerin geleceğe taşınmasında da önemli bir rol üstlenmektedir. Ancak özellikle son zamanlarda teknoloji ve sanayideki gelişmelerden dolayı seri üretimlerle birçok ürün üretildiği için ve el sanatlarına nazaran daha uygun fiyatlarla piyasada satıldı ̆̆ 1 için zanaatkârların azaldığı görülmektedir. Bazı kurum ve kuruluşların açtıkları kurslarla geleneksel el sanatlarının devam ettirilmesi amaçlansa da ekonomik döngüsünün olmaması nedeni ile sürdürülebilirlik noktasında sıkıntılar yaşanmaktadır. Bunda el sanatları ürünlerinin yeteri kadar ekonomik fayda getirmemesinin önemli payı bulunmaktadır.

Şırnak ili kendine özgü geleneksel el sanatları ile önemli kültürel değerlere sahiptir. Ancak bu değerlerin geleceğe taşınması oldukça zor bir duruma gelmiştir. Birkaç zanaatkâr dışında geleneksel el sanatlarını icra eden kalmamıştır. Şırnak'ta yöresel kıyafetlerin iplikleri eskiden yöre de üretiliyorken, şu an açılan kurslara bile iplikler yurt dışından getirilmektedir. $\mathrm{Bu}$ durum bölgenin istihdamına ve kalkınmasına olumsuz yönde etki etmektedir. Bu değerlerin yok olmasını engellemek için üretilen ürünlerin ekonomik bir faydaya dönüştürülerek sürdürülebilirliği sağlanmalıdır. Ek olarak kurumların açtığı geleneksel el sanatları kursları daha kapsamlı bir şekilde yapılmalıdır. Bunun için Şırnak genelinde açılan kursların birlik oluşturarak bir marka olușturmaları ve bu marka üzerinden hareket etmeleri oldukça önemlidir.

Gelenekler toplumların en değerli varlık sebebleridir ve sadece ticari amaçlarla kullanılmasının yanında kültürlerin kaybolmaması ve sürdürülebilirliği sağlama açısından yarar vardır. Ne yazık ki ekonominin bu denli insan hayatına hükmettiği çağımızda bazı gerçekleri görmek gerekir. Bugün yaşayan zanaatkârların çoğu baba mesleği olduğu için ve başka iş yapamayacakları korkusundan işleri devam ettirmek durumundadırlar. Ancak geleneksel el sanatları atölyesi veya işletmesi ekonomik sürdürülebilirliğini sağlaması gerekmektedir. El sanatlarının sürdürülebilmesi ve ticari amaçla kullanılması oldukça önemli ve zor bir konudur. Bunun için bütün paydaşların koordineli olarak çalışması gerekmektedir (Can, 2013).

Geleneksel el sanatlarının ekonomik fayda sağlamasının en önemli yolu turizmdir. Ancak henüz Şırnak'ta turizm konusunda gelişmeler olmadığından, geleneksel el sanatlarının şehir dışında, fuarlarda ve turistik merkezlerde tanıtımı ve satışı yapılabilir. Geleneksel el sanatlarının sürdürülebilmesi için turizm sektörünün katkısı dışında özel ve kamu kuruluşlarının geleneksel el sanatları kurslarının açılmasına, teşvik edilmesine ve markalaşmasına katkı sunmaları kültürel değerlerin yok olmasının önüne geçilmesinde etkili olacaktır. Özellikle geleneksel el sanatları noktasında çeşitli dernek ve vakıflar kurularak markalaşma yoluna gidilmesi, bunun ulusal ve uluslararası pazarlara sunulması ivedilikle yapılmalıdır.

Ülkemizde Ankara Olgunlaşma Enstitüsü, Kültür ve Turizm Bakanlığı, Geleneksel El Sanatları Vakfı, Milli Eğitim Bakanlığına bağlı il halk merkezleri gibi bazı kurumlar önemli çalışmalar yapmaktadırlar. Ancak ülkemizin her yerinde farklı sanatlar ve geleneksel el sanatları olmasından dolayı bu çalışmalar yeterli olamamaktadır. Bu yüzden başta Şırnak olmak üzere bütün illerimizdeki geleneksel el sanatlarının envanteri çıkarılmalıdır.

Bu çalışmada Şırnak'ın geleneksel el sanatları ele alınmış ve var olan potansiyeli ortaya konulmuştur. Bu alanda çalışan araştırmacılar, geleneksel el sanatlarının ekonomik etkilerini, marka haline getirilmesi ve üretim atölyelerinin geliştirilmesi noktalarına odaklanan projeler hazırlayarak, geleneksel el sanatlarının hem korunması hem de yöreye sağlayacağı katkıları arttırılabilir. Özel sektörün üretilen el sanatlarını pazarlama ve satışını gerçekleştirme noktasında ciddi adımlar atması hedeflere ulaşmada daha kolaylık sağlayabilir. Özel sektör ve kamu kurumlarının girişimleri ile "Şırnak Yöresel El Sanatları" adlı bir marka ortaya koyabilirler.

\section{Kaynakça}

Akköprü, B. (2015). Van İlinde El Sanatları Alanında Verilen Proje Destekleri ve Etkileri. Yüksek Lisans Tezi. Van: Van Yüzüncü Y1l Üniversitesi.

Akpınarlı F., \& Onuk T. (2005). Cumhuriyetten Günümüze El Sanatlarının Doğuşu, Gelişimi, Sosyal, Kültürel. İçinde: Eğitim ve Ekonomik İlişkiler Bakımında Bugün Ki Durumu ve Geleceği. V. Türk Kültür Sanatları Sempozyum Bildirileri, 13. Ankara: Atatürk Kültür Merkezi Yayınları. 
Bayazit, M., Ceylan, U., \& Saylan, U. (2012). Geleneksel El Sanatlarının Bölge Turizmine Etkisi: Güneydoğu Anadolu Bölgesi. Journal of Life Sciences, 1, 899-908.

Baz, İ., Şarman, N., \& Söyler, S. (2013). Şırnak Bastonu. Şırnak: Şırnak Üniversitesi Yayınları.

Baz, İ., Şarman, N., Çelik, S., Avcı, N., \& Kemaloğlu, S. A. (2012), Şırnak’ta Bir Atasporu Guhşegi, Şırnak: Şırnak Üniversitesi Yayınları.

Bendix, R. (1997). Folklorismus/Folklorism. In: Folklore: An Encyclopedia of Bliefs, Costums, Tales, Music, and Art, Green, T. A. (Ed.), (s.337-339). California: ABCCLIO.

Can, M. (2013). Geleneksel Türk El Sanatlarının Turizme ve Ekonomiye Katkısı. Sosyal ve Beşeri Bilimler Dergisi, 5(2), 259-266.

Etikan, S., \& Çukur, T. (2011). Kırsal turizm faaliyetlerinin Çomakdağ-Kızılağaç Köyü el sanatları üzerine etkisi. Art-e Sanat Dergisi, 4(8), 1-15.

Hacıoğlu, N. (2008). Turizm Pazarlamast. Ankara: Nobel Yayıncilik.

İbrahimoğlu, M. (2018). Yayınlanmamış Foto Arşivi, (TRT Muhabiri).

İde Sanat (2005). Şırnak İli Yöresel Kilim Motifleri. Şırnak: Şırnak Valiliği Basın ve Halkla İlişkiler Müdürlüğü. (Erişim: 13.02.2018), http://idesanat.com/images/upload /su8694.pdf

İdiman, F. (1999). 2000'li Yıllarda Türkiye'de Geleneksel El Sanatlarının Sanatsal, Tarımsal ve Ekonomik Boyutu. No: 2301. Ankara: Kültür ve Turizm Bakanlığı Yayınlar1.

John, S. (2014). A Study on the Role of Tourism in Promoting Arts and Crafts-A Case Study on Channapatna Toys. In: Proceedings of the Second International Conference on Global Business, Economics, Finance and Social Sciences, 11-13 July, India, 1-9.

Kılıçarslan, H., Etikan, S., \& Evecen, A. (2017). El Sanatlarında Ekonomik Kaygılarla Ortaya Çıkan Yeni Tasarımlar. Kalesmisi Dergisi, 5(9), 33-44.

Köybaşı, N. (2006). Boş Zaman Sosyolojisi ve Boş Zamanlarl Değerlendirme Aracl Olarak Dinlence Turizmi ve Kültür Turizmine Katılan Yerli Turistlerin Karşılaştırmalı Sosyolojik Analizi. Yüksek Lisans Tezi. Eskişehir: Anadolu Üniversitesi.

Mustafa, M. (2011). Potential of Sustaining Handicrafts as a Tourism Product in Jordan. International Journal of Business and Social Science, 2(2), 145-152.

Nyawo, J., \& Mubangizi, B. C. (2011). Art and Craft in Local Economic Development: Tourism Possibilities in Mtubatuba Local. Municipality. African Journal of Hospitality, Tourism and Leisure, 4(2), 1-15.

Okutan, B. B. (2012). Türkiye'de Popüler Kültür ve Din Illişkisi: Kadın Üzerine Bir Araştırma. Doktora Tezi. İstanbul: Marmara Üniversitesi.
Ölmez, F. N., \& Etikan, S. (2008). Kavramsal Açıdan El Sanatları Sorunsalı. İçinde: I. Ulusal El Sanatları Sempozyumu, Ankara Gazi Üniversitesi Türk El Sanatları Araştırma ve Uygulama Merkezi Yayınları, No.1.

Öter, Z. (2010). Türk El Sanatlarının Kültür Turizmi Bağlamında Değerlendirilmesi. Milli Folklor, 22 (86), 174-185.

Özcüre, G., \& Yavuz, C. (2006). El Sanatlar1 Ürünlerinin Bulunduğu Yöreye Sosyo Ekonomik Etkileri ve Katkıları (Ordu İli Örneği). İçinde: Uluslararası Katılımlı Sanat Ekonomisi Sempozyumu Kitabı, 167-183.

Rızaoğlu, B. (2016). Turizm Pazarlamass, Ankara: Detay Yayıncilık.

Sarıkaya Hünerel, Z., \& Er, B. (2012). Halk Kültürünün Tanıtılmasında El Sanatlarının Yeri ve Önemi. Batman Üniversitesi Yaşam Bilimleri Dergisi, 1(1), 179-190

Şahin, H. İ. (2009). Dalyan ve Köyceğiz Çevresinde Gelenek, Turizm ve Folklorizm. Milli Folklor, 21 (82), 50-58.

Şırnak Kültür ve Turizm İl Müdürlüğü (2017). El Sanatlart. (Erişim: 19.12.2017), http://www.sirnakkulturturizm. gov.tr/TR,56451/el-sanatlari.html

Tjoa, A. M., \& Wagner, R. R. (1998). The Role of Handicraft Production and Art in Tourism and its Presentation in the Internet. In: Buhalis, D. (Ed.), Information and Communication Technologies in Tourism 1998 (pp. 338344). Vienna: Springer.

Top, M. (2009). Şırnak Kültür Envanteri, Ankara: Anıt Matbaa.

Tunç, A., \& Saç, F. (1998). Genel Turizm. Ankara: Detay Yayıncılık.

TÜRSAB (2017). Turizmin Ekonomideki Yeri. (Erişim:18.01.2018), https://www.tursab.org.tr/tr/turizm verileri/istatistikler/turizmin-ekonomideki-yeri/disticaret-aciklarini-kapatmada-payi_916.html

Usta, Ö. (2014). Turizm Genel ve Yapısal Yaklaşım. Ankara: Detay Yayıncilık.

Yanar, A., \& Arlı, M. (2014). Turistik Hediyelik Eşyada Kimlik Bilgisinin Önemi. İçinde: VII. Lisansüstü Turizm Öğrencileri Araştırma Kongre Kitabı, 04-05 Nisan, Kuşadası, 16-26.

Zargham, H. (2007). Sustainable Tourism Development and Handicrafts in the Developing World. Transactions on Ecology and the Environment, 102, 111-117. 